\title{
Role of $\mathrm{Mg}^{2+}$ in the structure and activity of maize (Zea mays L.) isocitrate lyase: indications for hysteretic behaviour
}

\author{
Sonia BEECKMANS ${ }^{1}$, A. Salam KHAN and Edilbert VAN DRIESSCHE \\ Department of Protein Chemistry, Vrije Universiteit Brussel, Paardenstraat 65, B-1640 Sint-Genesius-Rode, Belgium
}

\begin{abstract}
The role of $\mathrm{Mg}^{2+}$ in the structure and activity of maize isocitrate lyase has been studied by $\mathrm{CD}$, limited proteolysis, protection by ligands against inactivation, and activity measurements at various metal concentrations. From CD and trypsinolysis experiments, the existence of high-affinity binding sites for $\mathrm{Mg}^{2+}$ was demonstrated, and a $K_{\mathrm{dME}}$ of $200 \mu \mathrm{M}$ was determined. Both free enzyme (E) and enzyme molecules with high-affinity sites occupied (ME) are catalytically competent, the former showing $40 \%$ of the activity of the latter. $\mathrm{Mg}^{2+}$ thus acts as a non-essential activator. A second $\mathrm{Mg}^{2+}$-binding site with a $K_{\mathrm{dM} \mathrm{EM}}$ of $6 \mathrm{mM}$ was revealed from protection experiments by increasing $\mathrm{Mg}^{2+}$ concentrations against inactivation. From activity measurements at different
\end{abstract}

$\mathrm{Mg}^{2+}$ concentrations, the affinity of the enzyme for the $\mathrm{Mg}^{2+}$ isocitrate complex (MI) was determined to be $K_{\mathrm{dE}(\mathrm{MI})}=9 \mu \mathrm{M}$. Maize isocitrate lyase was shown to display hysteretic behaviour. Filling the low-affinity binding sites with $\mathrm{Mg}^{2+}$ induces a conformational change in the high-affinity binding sites resulting in an even higher affinity for $\mathrm{Mg}^{2+}\left(K_{\mathrm{dME}^{*}}=40 \mu \mathrm{M}\right)$. On lowering the $\mathrm{Mg}^{2+}$ concentration again, the enzyme only responds slowly: the time needed for all enzyme molecules to return to the conformation at which $K_{\mathrm{dME}}$ is $200 \mu \mathrm{M}$ was found to be $60 \mathrm{~min}$. Finally it was shown that the high-affinity binding site for $\mathrm{Mg}^{2+}$ is not formed at low $\left(4{ }^{\circ} \mathrm{C}\right)$ temperature.

\section{INTRODUCTION}

Isocitrate lyase (EC 4.1.3.1), one of the glyoxylic acid-cycle enzymes, catalyses the reversible cleavage of isocitrate to glyoxylate and succinate. The enzyme relies absolutely on the presence of $\mathrm{Mg}^{2+}$ ions for its activity. Optimal catalytic rates are observed, for plant as well as bacterial and fungal isocitrate lyases, at $\mathrm{Mg}^{2+}$ concentrations of between 1.5 and $8 \mathrm{mM}$ [1-3]. Higher concentrations have been shown to be inhibitory. Isocitrate lyase from maize is a tetrameric protein consisting of identical subunits with a molecular mass of $64 \mathrm{kDa}$ each [4].

The existence of two classes of $\mathrm{Mg}^{2+}$-binding site with different affinities was suggested for Ricinus isocitrate lyase by Malhotra et al [5]. It should be noted, however, that these studies were performed in phosphate buffer, which is known to chelate $\mathrm{Mg}^{2+}$ ions, and the very complex interactions between the cation on the one hand and the enzyme, substrate and buffer on the other were not taken into account.

More recently, Giachetti et al. [6,7] performed detailed kinetic studies with Pinus pinea isocitrate lyase, using triethanolamine and Hepes buffers. These authors concluded unequivocally that the $\mathrm{Mg}^{2+}$-isocitrate complex is the true substrate for isocitrate lyase. Moreover, $\mathrm{Mg}^{2+}$ also binds to distinct high-affinity binding sites, thereby acting as a 'non-essential activating ion': both activated and non-activated enzyme forms were indeed found to be catalytically active. Similar behaviour was reported for isocitrate lyase from the filamentous fungus Cephalosporium acremonium [8].

In the present paper we describe studies on the association of $\mathrm{Mg}^{2+}$ ions with maize isocitrate lyase. Moreover, on the basis of our results, a model is presented of hysteretic cation binding of this enzyme.

\section{MATERIALS AND METHODS}

\section{Enzyme preparation and assay}

Isocitrate lyase was purified from maize seedlings and stored as described previously by us [4]. SDS/PAGE showed that our preparation consisted of a single type of subunit (64 kDa), with no trace of contamination with the $62 \mathrm{kDa}$ polypeptide (see remarks in ref. [4]).

Isocitrate lyase activity was assayed spectrophotometrically at $25^{\circ} \mathrm{C}$ by the continuous method of Dixon and Kornberg [9] with modifications. The substrate solution consisted of $4 \mathrm{mM}$ D,Lisocitric acid, $5 \mathrm{mM} \mathrm{MgCl} 2,6 \mathrm{H}_{2} \mathrm{O}, 3 \mathrm{mM}$ cysteine, $4 \mathrm{mM}$ phenylhydrazine and $50 \mathrm{mM}$ triethanolamine, $\mathrm{pH}$ 7.4. One unit of isocitrate lyase activity is the amount that catalyses the cleavage of $1 \mu \mathrm{mol}$ of isocitrate/min under the conditions described. In a number of experiments (as mentioned below), $\mathrm{MgCl}_{2}$ was omitted from the reaction mixture. In view of the metal-chelating properties of phosphate $[10,11]$, this buffer was replaced by triethanolamine. Glyoxylate formed during the enzymic conversion of isocitrate reacts with phenylhydrazine, forming the corresponding hydrazone $\left(\epsilon_{324 \mathrm{~nm}}=17000 \mathrm{M}^{-1} \cdot \mathrm{cm}^{-1}\right)$. Since this chemical reaction requires a certain time to reach steady-state, measurements were recorded starting $3 \mathrm{~min}$ after the onset of activity; in all our assays, absorbance was found to increase linearly for at least another $5 \mathrm{~min}$. Under these conditions, the specific activity of pure isocitrate lyase was found to be 4.95 units/mg (i.e. identical with the value obtained using the experimental conditions of Dixon and Kornberg [9]).

\section{Preparation of isocitrate lyase solutions}

All experiments described below were performed with isocitrate lyase dissolved in $80 \mathrm{mM}$ triethanolamine, $\mathrm{pH} 7.6$, containing $0.2 \mathrm{mM}$ dithiothreitol and various concentrations of $\mathrm{MgCl}_{2}$ (from 0 up to $240 \mathrm{mM}$ ).

Metal-free isocitrate lyase was prepared as described previously [4]. Complete removal of the EDTA was performed by extensive dialysis $(40 \mathrm{~h})$ against buffer.

\section{Reagents}

The substrate for isocitrate lyase was purchased from Sigma: in all experiments threo- $\mathrm{D}_{\mathrm{S}} \mathrm{L}_{\mathrm{S}}$-isocitric acid was used, which contains

\footnotetext{
1 To whom correspondence should be addressed.
} 
$50 \%$ of the true substrate, namely the $\mathrm{D}_{\mathrm{s}}$-isomer. In preliminary experiments, we confirmed that $\mathrm{L}_{\mathrm{S}}$-isocitrate is neither substrate nor inhibitor of maize isocitrate lyase, as observed by other authors for different isocitrate lyases [2]. For all calculations, a $K_{\mathrm{d}}$ of $0.74 \mathrm{mM}$ was used for binding of $\mathrm{Mg}^{2+}$ to isocitrate [12].

Tos-Phe- $\mathrm{CH}_{2} \mathrm{Cl}$-treated trypsin, PMSF, dithiothreitol and triethanolamine were also from Sigma. Ultrapure disodium EDTA was purchased from Fluka Chemie AG. All other reagents were pro-analysis grade. Before use, acrylamide and $N, N^{\prime}$ methylenebisacrylamide were recrystallized from acetone and chloroform respectively.

\section{CD}

CD spectra were recorded with a Cary 61 spectropolarimeter. Ellipticities were calculated using the equation:

$\left[\theta_{\lambda}\right]=(\mathrm{MRW} / 100) \times\left(\theta_{\lambda} / c d\right)$

where the mean residual weight (MRW) is 110 , and $c$ and $d$ stand for enzyme concentration (in $\mathrm{g} / \mathrm{ml}$ ) and optical path length (in $\mathrm{dm})$ respectively.

\section{Limited proteolysis}

A kinetic study of tryptic degradation of isocitrate lyase was performed as follows. A stock solution of Tos-Phe- $\mathrm{CH}_{2} \mathrm{Cl}-$ treated trypsin was prepared by dissolving $5 \mathrm{mg}$ in $1 \mathrm{ml}$ of $1 \mathrm{mM}$ $\mathrm{HCl}$. This solution was stored at $4{ }^{\circ} \mathrm{C}$. To $0.5 \mathrm{ml}$ of isocitrate lyase solution $(0.35 \mathrm{mg} / \mathrm{ml})$ containing different concentrations of $\mathrm{MgCl}_{2}$ was added $7 \mu \mathrm{l}$ of stock trypsin solution. After various time intervals, a sample $(50 \mu \mathrm{l})$ was taken and proteolytic degradation was stopped instantaneously by the addition of $50 \mu \mathrm{l}$ of a freshly prepared stock PMSF solution $(40 \mathrm{mM}$ reagent in ethanol). These samples were stored at $-20{ }^{\circ} \mathrm{C}$ until analysis by SDS/PAGE as described by Laemmli [13].

\section{RESULTS AND DISCUSSION}

The presence of $\mathrm{Mg}^{2+}$ ions is known to be essential for the catalytic activity of isocitrate lyase [1-4]. Since the cation quite easily dissociates from the enzyme, isocitrate lyase should be classified as a metal-activated enzyme [10] rather than a true metalloenzyme.

The experimental results presented in this paper on maize isocitrate lyase enable us to determine the dissociation constants, $K_{\mathrm{d}}$, for binding of $\mathrm{Mg}^{2+}$ ions to distinct sites of the enzyme. Moreover, they lead to the proposal of a model of hysteretic behaviour.

All calculations presented are based on both the general definition of $K_{\mathrm{d}}$, from which the concentrations of all possible species in a mixture containing enzyme, substrate and $\mathrm{Mg}^{2+}$ can be estimated, and the classical equation:

$v=V_{\max }[\mathrm{MI}] /\left(K_{\mathrm{m}}+[\mathrm{MI}]\right)$

where $\mathrm{MI}$ is $\mathrm{Mg}^{2+}$-isocitrate complex.

\section{Effect of $\mathrm{Mg}^{2+}$ on the CD spectrum in the near-UV region: determination of $\boldsymbol{K}_{\mathrm{dME}}$}

The CD spectrum of isocitrate lyase at $25^{\circ} \mathrm{C}$ (in $80 \mathrm{mM}$ triethanolamine, $\mathrm{pH} 7.6$, containing $0.2 \mathrm{mM}$ dithiothreitol and $6 \mathrm{mM} \mathrm{MgCl}$ ) is presented in Figure 1. It exhibits a negative as well as a positive Cotton effect with minima at 261 and $267.5 \mathrm{~nm}$ and maxima at 285 and $291 \mathrm{~nm}$ respectively. The latter maxima may be ascribed to the presence of (a) tryptophan residue(s) located in an asymmetric environment [14]. On removal of the metal, the value of the maximum at $291 \mathrm{~nm}$ was found to

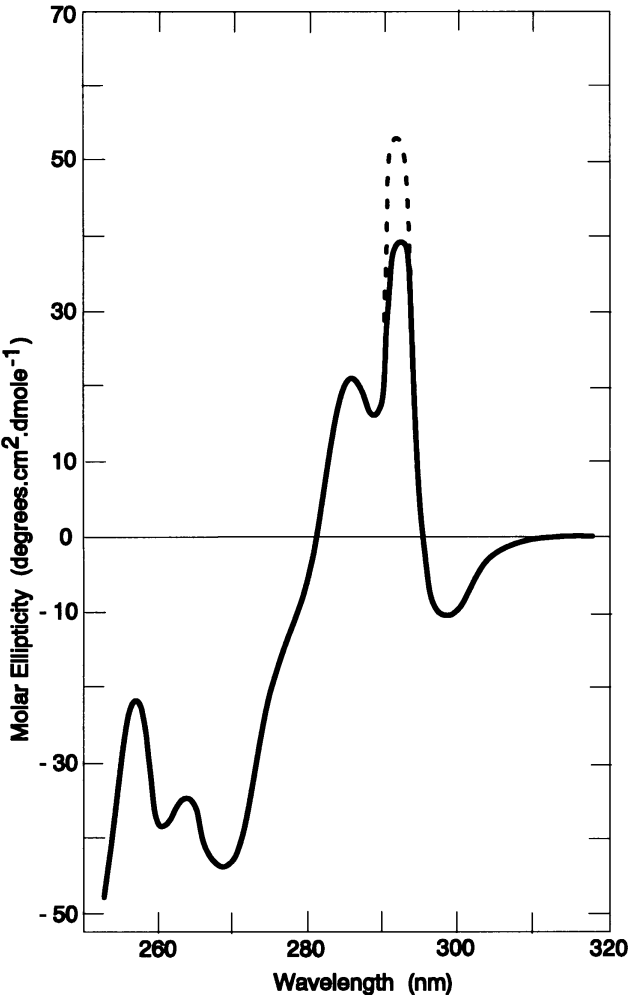

Figure 1 CD spectra of maize isocitrate lyase in the near-UV region

, Spectrum of the enzyme $(0.3-0.6 \mathrm{mg} / \mathrm{ml}$ in $80 \mathrm{mM}$ triethanolamine buffer, $\mathrm{pH} 7.6$, containing $0.2 \mathrm{mM}$ dithiothreitol) in the presence of $6 \mathrm{mM} \mathrm{MgCl}_{2}$; ----, on removal of the metal, the spectrum differs exclusively in the magnitude of the peak at $291 \mathrm{~nm}$.

Table 1 Molar ellipticities at $291 \mathrm{~nm}$ of native and metal-free maize isocitrate lyase, as well as the ellipticities observed when metal-free enzyme is incubated at $25{ }^{\circ} \mathrm{C}$ in the presence of increasing $\mathrm{MgCl}_{2}$ concentrations

The dissociation constant of isocitrate lyase for $\mathrm{Mg}^{2+}$ is calculated from these results

\begin{tabular}{lcll}
\hline Isocitrate lyase & $\begin{array}{c}{\left[\mathrm{MgCl}_{2}\right]} \\
(\mathrm{mM})\end{array}$ & $\begin{array}{l}{\left[\theta_{291 \mathrm{~nm}}\right]} \\
\left(\text { degrees } \cdot \mathrm{cm}^{2} \cdot \mathrm{dmol}^{-1}\right)\end{array}$ & $\begin{array}{l}K_{\mathrm{d}} \\
(\mu \mathrm{M})\end{array}$ \\
\hline Native & 6.0 & 38.0 & - \\
Metal-free & 240 & 38.0 & - \\
Remetallized & 0 & 52.0 & - \\
& 0.1 & 47.2 & 192 \\
& 0.2 & 45.0 & 200 \\
& 0.6 & 41.6 & 196 \\
& 1.0 & 40.3 & - \\
& 6.0 & 38.0 & - \\
& 60 & 38.0 & \\
\end{tabular}

increase from 38.0 to 52.0 degrees $\cdot \mathrm{cm}^{2} \cdot \mathrm{dmol}^{-1}$, indicating that the environment of the above-mentioned tryptophan residue(s) is slightly different in metal-free isocitrate lyase from that in the $\mathrm{Mg}^{2+}$-bound enzyme. No spectral differences were observed in the CD spectrum in the far-UV region (results not shown).

When $\mathrm{Mg}^{2+}$ ions are gradually added (from a stock solution of $0.6 \mathrm{M} \mathrm{MgCl}_{2}$ in triethanolamine) to metal-free enzyme at $25^{\circ} \mathrm{C}$, the value at $291 \mathrm{~nm}$ decreases until the original spectrum is obtained when $\mathrm{MgCl}_{2}$ is added at a final concentration of $6 \mathrm{mM}$. From these results, which are summarized in Table 1, a dis- 

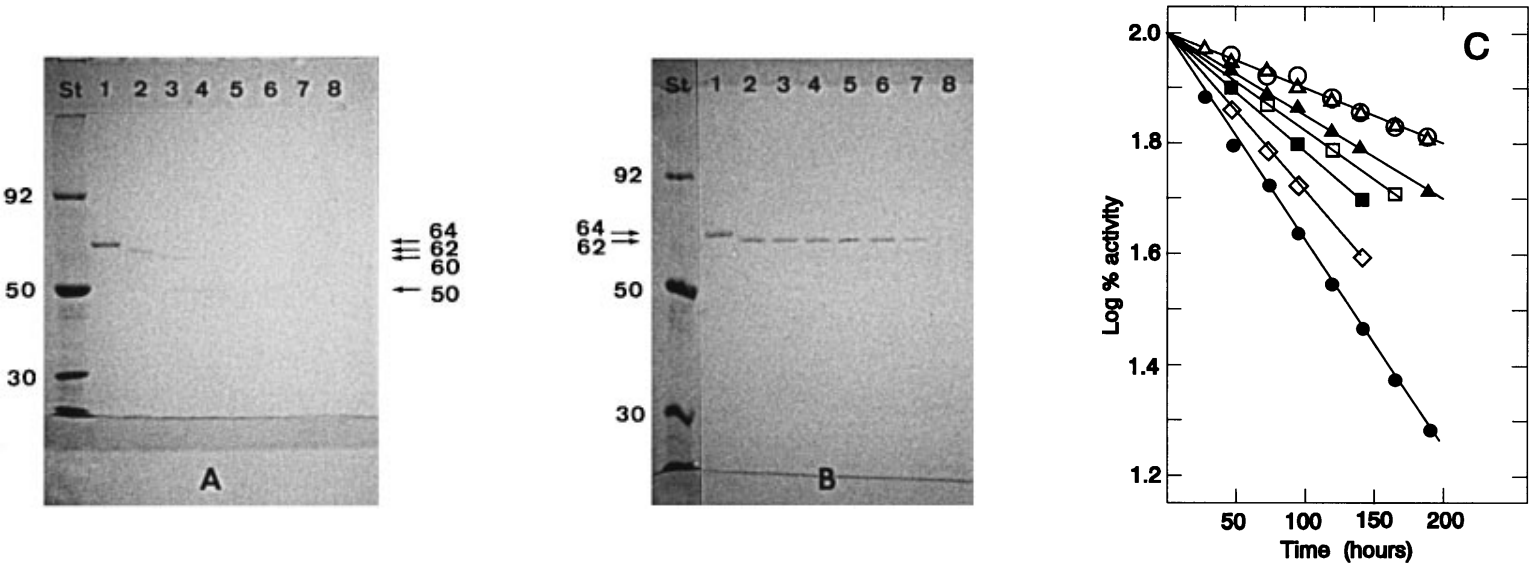

\section{Figure 2 Limited proteolysis of maize isocitrate lyase}

(A,B) Limited proteolysis of maize isocitrate lyase $(0.35 \mathrm{mg} / \mathrm{ml})$ as studied by SDS/PAGE. Proteolysis with trypsin/TOS-Phe-CH $\mathrm{Cl}_{2}(1: 20$, w/w) was allowed to proceed in the presence of increasing $\mathrm{Mg}^{2+}$ concentrations: $\mathrm{no} \mathrm{MgCl}_{2}$ (metal-free enzyme) (A), and $0.6 \mathrm{mM} \mathrm{MgCl}(\mathbf{B})$; the same pattern (as in B) is observed when proteolysis is performed in the presence of $6 \mathrm{mM} M g C l, 6 \mathrm{mM}$ $\mathrm{MgCl}_{2}+6 \mathrm{mM} \mathrm{D}, \mathrm{L}$-isocitrate, or $60 \mathrm{mM} \mathrm{MgCl}$. In lane 1, pure isocitrate lyase is shown. The enzyme was subjected to degradation for different periods of time: $30 \mathrm{~s}$ (lane 2), 15 min (lane 3 ), $30 \mathrm{~min}$ (lane 4), $60 \mathrm{~min}$ (lane 5), $90 \mathrm{~min}$ (lane 6), $120 \mathrm{~min}$ (lane 7) and $240 \mathrm{~min}$ (lane 8). St, mixture of standard proteins of known molecular mass, i.e. phosphorylase $b$ (92 kDa), fumarase $(50 \mathrm{kDa})$ and carbonic anhydrase $(30 \mathrm{kDa})$. This experiment was performed three times, and the electrophoretic pattern was found to be highly reproducible. (C) Gradual inactivation of maize isocitrate lyase as a function of $\mathrm{Mg}^{2+}$ concentration. The enzyme $(0.12 \mathrm{mg} / \mathrm{ml})$ was buffered with $80 \mathrm{mM}$ triethanolamine, $\mathrm{pH}$ 7.6, containing $0.2 \mathrm{mM}$ dithiothreitol, and samples contained $6 \mathrm{mM}(\mathbf{O})$, $12 \mathrm{mM}(\diamond), 24 \mathrm{mM}(\boldsymbol{\square}), 36 \mathrm{mM}(\square), 60 \mathrm{mM}(\boldsymbol{\Delta}), 240 \mathrm{mM}(\triangle)$ and $300 \mathrm{mM}(\bigcirc) \mathrm{MgCl}_{2}$

sociation constant of $200 \mu \mathrm{M}$ for the binding of $\mathrm{Mg}^{2+}$ to isocitrate lyase was calculated by using the equation:

$\left([\theta]-\left[\theta_{\mathrm{f}}\right]\right) M /\left(\left[\theta_{\mathrm{o}}\right]-[\theta]\right)$

where $\left[\theta_{\mathrm{o}}\right]$ and $\left[\theta_{\mathrm{f}}\right]$ are the molar ellipticity values of metal-free and fully metallized enzyme respectively, and $[\theta]$ is the molar ellipticity at an intermediate $\mathrm{MgCl}_{2}$ concentration $M$. If, however, $\mathrm{MgCl}_{2}$ is added to metal-free isocitrate lyase at $4{ }^{\circ} \mathrm{C}$, and if the enzyme is continuously kept at this low temperature, the maximum at $291 \mathrm{~nm}$ remains at 52.0 degrees $\cdot \mathrm{cm}^{2} \cdot \mathrm{dmol}^{-1}$, even after the addition of $60 \mathrm{mM} \mathrm{MgCl}$.

The dissociation constant for $\mathrm{Mg}^{2+}\left(K_{\mathrm{dME}}=200 \mu \mathrm{M}\right)$ is in very good agreement with the value found for the binding of this cation to the non-catalytic high-affinity site of $P$. pinea isocitrate lyase $\left(K_{\mathrm{dME}}=190 \mu \mathrm{M}\right)[6]$ and also of $C$. acremonium isocitrate lyase $\left(K_{\mathrm{dME}}=300 \mu \mathrm{M}\right)[8]$. We conclude that, like Pinus and Cephalosporium isocitrate lyase, the enzyme from maize has a high-affinity site for $\mathrm{Mg}^{2+}$. At least one tryptophan residue is postulated to reside in the vicinity of the bound $\mathrm{Mg}^{2+}$.

\section{Limited proteolysis of isocitrate lyase}

The existence of such a high-affinity binding site was confirmed by limited proteolysis with trypsin. Metal-free isocitrate lyase is immediately proteolysed in the presence of $1: 20(\mathrm{w} / \mathrm{w})$ trypsin/Tos-Phe- $\mathrm{CH}_{2} \mathrm{Cl}$ to yield small peptides (Figures $2 \mathrm{~A}$ and 2B). Only traces of 62 and $60 \mathrm{kDa}$ and of 60 and $50 \mathrm{kDa}$ fragments are observed 0.5 and $15 \mathrm{~min}$ respectively after the addition of trypsin. Isocitrate lyase in the presence of $0.6 \mathrm{mM}$ $\mathrm{MgCl}_{2}, 6 \mathrm{mM} \mathrm{MgCl}$ (in the absence or presence of $6 \mathrm{mM} \mathrm{D,L-}$ isocitrate), or $60 \mathrm{mM} \mathrm{MgCl}$ is degraded immediately (i.e. after $30 \mathrm{~s}$ ) to an inactive fragment with a molecular mass of $62 \mathrm{kDa}$. This high-molecular-mass intermediate was found to be highly stable, since no further degradation whatsoever appears to occur, not even after $4 \mathrm{~h}$ of incubation. Binding of $\mathrm{Mg}^{2+}$ to the highaffinity site of isocitrate lyase thus protects the enzyme against complete proteolytic degradation. It is noteworthy that, in maize seedling extracts also, an inactive $62 \mathrm{kDa}$ fragment of isocitrate lyase is detected, especially when the seedlings are grown for 3 days or longer (for a detailed discussion, see ref. [4]). A peptide bond about 18 residues from either the $\mathrm{N}$ - or $\mathrm{C}$-terminus of the protein molecule thus appears to be exposed to the surface and is very susceptible to proteolytic attack.

\section{Kinetics of isocitrate lyase inactivation: determination of $\boldsymbol{K}_{\mathrm{dMEM}}$}

Isocitrate lyase is gradually inactivated on incubation in triethanolamine buffer at $25^{\circ} \mathrm{C}$. This inactivation slows down markedly when the $\mathrm{Mg}^{2+}$ concentration is increased (Figure 2C). Maximal stabilization is reached at $240 \mathrm{mM} \mathrm{MgCl}_{2}$. From these results, a second dissociation constant of $6 \mathrm{mM}$ can be calculated for $\mathrm{Mg}^{2+}$ binding to isocitrate lyase. For our $K_{\mathrm{d}}$ determination we used the method described by Beeckmans and Kanarek [15], i.e. we made use of the eqns (1) $M E+M E M=1$ and (2) $k_{\mathrm{o}} \mathrm{ME}+k_{\mathrm{f}} \mathrm{MEM}=k$, where $k_{\mathrm{o}}$ and $k_{\mathrm{f}}$ are respectively the rate constants of inactivation of enzyme molecules ME and MEM, and $k$ is the rate constant at intermediate concentrations of $M$. Kinetic constants were calculated from the half-lives of inactivation $\left(k t_{\frac{1}{2}}=0.693\right)$. The rate constant for fully occupied maize isocitrate lyase $\left(k_{\mathrm{f}}\right)$ was found to be $2.31 \times 10^{-3} \mathrm{~h}^{-1}$, and $k$ $=8.66 \times 10^{-3} \mathrm{~h}^{-1}$ at a $\mathrm{Mg}^{2+}$ concentration of $6 \mathrm{mM}$. The $k_{\mathrm{o}}$ value on the other hand could not be determined experimentally in a direct way since no $\mathrm{Mg}^{2+}$ concentration can be found that is sufficiently higher than the above-determined $K_{\mathrm{d}}$ of $200 \mu \mathrm{M}$, but low enough to leave the second binding site empty. However, we estimated it to be $15.0 \times 10^{-3} \mathrm{~h}^{-1}$ since, with this $k_{\mathrm{o}}$, we calculate $K_{\mathrm{d}}$ values, at the different $\mathrm{Mg}^{2+}$ concentrations $(6-60 \mathrm{mM})$, that are nicely spread around the mean value of $5.94 \pm 0.05 \mathrm{mM}$; lower (respectively higher) $k_{\mathrm{o}}$ estimates result in $K_{\mathrm{d}}$ values that decrease (respectively increase) with increasing $\mathrm{Mg}^{2+}$ concentrations, and moreover the standard deviation becomes appreciably higher.

The observed protection against inactivation by increasing $\mathrm{Mg}^{2+}$ concentrations thus reveals the presence of a second $\mathrm{Mg}^{2+}$ binding site with $K_{\mathrm{dMEM}}=6 \mathrm{mM}$. This value is exactly the same as that determined by Giachetti et al. [6] for binding of $\mathrm{Mg}^{2+}$ in 

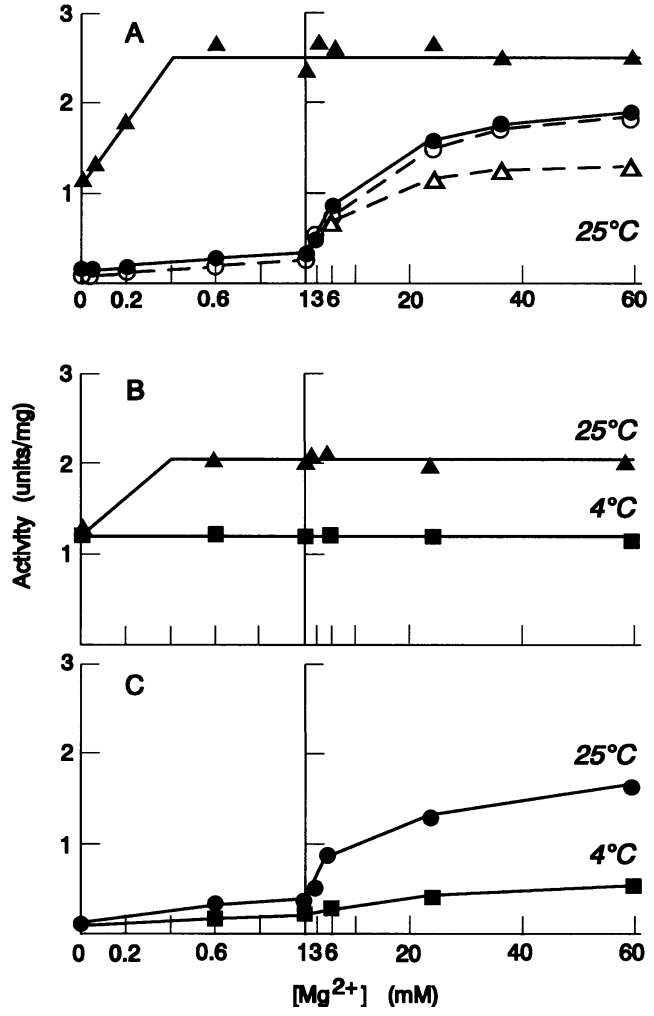

Figure 3 Activity on remetallization of maize isocitrate lyase

(A) The enzyme $(0.1 \mathrm{mg} / \mathrm{ml})$ was first demetallized and then incubated for $1 \mathrm{~h}$ at $25^{\circ} \mathrm{C}$ in the presence of increasing concentrations of $\mathrm{MgCl}_{2}$ as indicated on the abscissa. The activity of the samples was measured in either the absence $(\mathbf{)}$ ) or presence $(\boldsymbol{\Delta})$ of $5 \mathrm{mM} \mathrm{MgCl}$ in the assay solution. In conditions where enzyme activity was measured without $\mathrm{MgCl}_{2}$ in the assay solution, the observed values were compared with the theoretical values calculated according to a model without $\left(K_{\mathrm{dME}}=200 \mu \mathrm{M}\right)(\triangle)$ and with $\left(K_{\mathrm{dME}}=40 \mu \mathrm{M}\right)(\bigcirc)$ hysteretic binding of $\mathrm{Mg}^{2+}$ ions (see the text for details). (B,C) Activity of remetallized isocitrate lyase. The enzyme $(0.1 \mathrm{mg} / \mathrm{ml})$ was first demetallized and then incubated for $1 \mathrm{~h}$ at $4{ }^{\circ} \mathrm{C}$ in the presence of increasing $\mathrm{MgCl}_{2}$ concentrations. Activities ( $\left.\mathbf{\square}\right)$ were measured with $(\mathbf{B})$ and without $(\mathbf{C}) \mathrm{MgCl}_{2}$ in the assay solution. Finally, the samples were incubated for another hour at $25^{\circ} \mathrm{C}$ and the activities were again measured in the presence $(\boldsymbol{\Delta})$ or absence $(\mathbf{O})$ of $\mathrm{MgCl}_{2}$ in the assay solution.

the active site of $P$. pinea isocitrate lyase, and corroborates the $K_{\mathrm{dMEM}}$ of $5.7 \mathrm{mM}$ found for the $C$. acremonium enzyme [8].

\section{Catalytic competence of $\mathrm{E}$ and $\mathrm{ME}$}

Metal-free enzyme was incubated at $25^{\circ} \mathrm{C}$ in the presence of increasing concentrations of $\mathrm{MgCl}_{2}$, and its enzyme activity was measured using the classic assay solution, i.e. supplemented with $5 \mathrm{mM} \mathrm{MgCl}_{2}$ (Figure 3A). In our experimental conditions, a maximum of $50 \%$ of the original activity was recovered when $0.6 \mathrm{mM} \mathrm{MgCl}{ }_{2}$ was present in the protein sample. The addition of higher $\mathrm{MgCl}_{2}$ concentrations, up to $60 \mathrm{mM}$, was not found to improve the re-activation, and neither did the presence of $6 \mathrm{mM}$ $\mathrm{MgCl}_{2}+6 \mathrm{mM}$ D,L-isocitrate. Since after a second demetallization, followed by incubation of the enzyme once more in the presence of $\mathrm{MgCl}_{2}$, even less activity was regained (namely $17 \%$ ), we assume that $50 \%$ re-activation after the first round should be interpreted as half of the total number of enzyme molecules re-activating to their initial activity, rather than all molecules reshuffling to a conformation that is only $50 \%$ active.

When taking this into account, the metal-free isocitrate lyase molecules display an enzyme activity of 1.07 units/mg, which

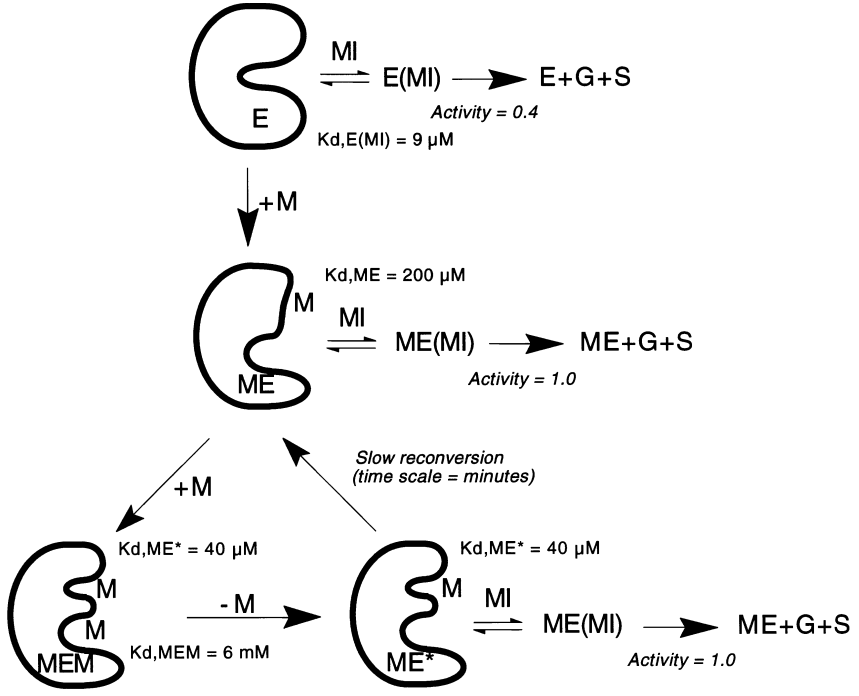

Scheme 1 Possible isocitrate lyase conformers and their kinetics (see text for further details)

The following nomenclature is used. (a) Ligands: I, threo-Ds-isocitrate; $\mathrm{M} \mathrm{Mg}^{2+}$ cation; $\mathrm{MI}$, $\mathrm{Mg}^{2+}$-threo-DS-isocitrate complex; $\mathrm{S}$, succinate; G, glyoxylate. (b) Enzyme species: E, isocitrate lyase without any ligand bound; $M E$, isocitrate lyase in which the non-catalytic high-affinity site for $\mathrm{Mg}^{2+}$ is occupied; $\mathrm{E}(\mathrm{MI})$, isocitrate lyase in which the active site is occupied with $\mathrm{MI}$; $M E(M I)$, isocitrate lyase with both the high-affinity and the active sites occupied, i.e. respectively with $\mathrm{M}$ and $\mathrm{MI}$; MEM, isocitrate lyase with both high- and low-affinity sites occupied with $\mathrm{M}$; $\mathrm{ME}^{*}$, isocitrate lyase in which the non-catalytic high-affinity site for $\mathrm{Mg}^{2+}$ is occupied, and has undergone a conformational change.

amounts to $40 \%$ of the activity exhibited by the fully metallized enzyme, i.e. 2.64 units/mg (Figure 3A). As the non-catalytic high-affinity $\mathrm{Mg}^{2+}$-binding site is gradually filled with the cation, intermediate enzyme activities are observed. Our data are thus consistent with the following model, depicted in Scheme 1 (top). Both $\mathrm{E}$ and $\mathrm{ME}$ are catalytically competent, but maximal activity of the former only amounts to $40 \%$ of the activity of the latter. This finding is in agreement with the results obtained by Giachetti et al. [6], who observed that for Pinus isocitrate lyase $V_{\max . \mathrm{E}}=$ $0.63 V_{\max . \mathrm{ME}}$. For $C$. acremonium isocitrate lyase on the other hand, $V_{\operatorname{max.E}}=0.21 V_{\operatorname{max.ME}}[8]$.

When remetallization of isocitrate lyase is allowed to proceed at low $\left(4^{\circ} \mathrm{C}\right)$ temperature (Figures $3 \mathrm{~B}$ and $3 \mathrm{C}$ ), activity was observed to be totally independent of the $\mathrm{MgCl}_{2}$ concentration added to the sample (i.e. $40 \%$ of the activity, recovered when the re-activation took place at $25^{\circ} \mathrm{C}$ ). We conclude that the enzyme is 'frozen' into its conformation and unable to restore its high-affinity binding site at $4{ }^{\circ} \mathrm{C}$. This hypothesis is confirmed by CD measures: as long as the enzyme is stored at $4{ }^{\circ} \mathrm{C}$, the value of the maximum at $291 \mathrm{~nm}$ remains at 52.0 degrees $\cdot \mathrm{cm}^{2} \cdot \mathrm{dmol}^{-1}$ irrespective of the concentration of the $\mathrm{MgCl}_{2}$ added. When the temperature is finally allowed to rise to $25^{\circ} \mathrm{C}$, the maximum decreases to its original value and, concomitantly, enzyme activity increases to about the same values as those observed for isocitrate lyase that was allowed to re-activate directly at $25^{\circ} \mathrm{C}$.

\section{Determination of $\boldsymbol{K}_{\mathrm{dE}(\mathrm{MI})}$}

From simple activity measurements of isocitrate lyase (dissolved in triethanolamine buffer, $\mathrm{pH} 7.6$, containing $0.2 \mathrm{mM}$ dithiothreitol and $6 \mathrm{mM} \mathrm{MgCl}$ ) determined in the absence of $\mathrm{MgCl}_{2}$ in the assay solution, we were able to estimate the dissociation constant of the enzyme for $\mathrm{Mg}^{2+}$-isocitrate (MI). In such 

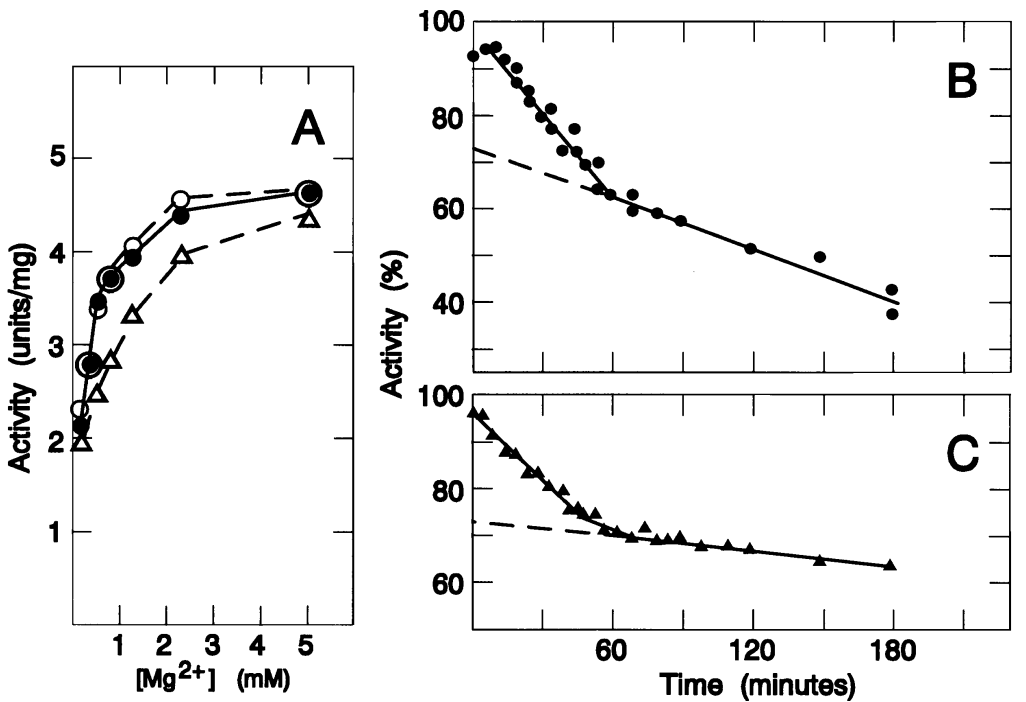

Figure 4 Hysteretic behaviour of isocitrate lyase

(A) The activity of an isocitrate lyase sample $(0.12 \mathrm{mg} / \mathrm{ml})$ containing $240 \mathrm{mM} \mathrm{MgCl}$, was measured in assay solution containing no $\mathrm{MgCl}_{2}$. The observed activities ( $)$ are compared with theoretical curves calculated according to a model with $\left(K_{\mathrm{dME}}=40 \mu \mathrm{M}\right)(\triangle)$ and without $\left(K_{\mathrm{dME}}=200 \mu \mathrm{M}\right)(\bigcirc)$ hysteretic binding of $\mathrm{Mg}^{2+}$ ions (see the Discussion for details). (B,C) Two isocitrate lyase solutions $[0.37 \mathrm{mg} / \mathrm{ml},(\mathbf{B})$ and $2.4 \mathrm{mg} / \mathrm{ml}(\mathbf{C})]$ containing $240 \mathrm{mM} \mathrm{MgCl}_{2}$ were diluted 1000 times and their activities measured using the assay solution containing $5 \mathrm{mM} \mathrm{MgCl}_{2}$.

experiments the $\mathrm{Mg}^{2+}$ concentration during the assay will depend exclusively on the amount of sample added to the cuvette. Our experimental conditions were chosen in such a way that isocitrate lyase adopted the unliganded conformation, E, displaying a maximum activity of 2.0 units/mg (i.e. $40 \%$ of the activity of the fully metallized enzyme, as determined above).

An isocitrate lyase solution with a specific activity of 4.95 units/mg when assayed in the presence of $5 \mathrm{mM} \mathrm{MgCl}_{2}$ showed only an activity of $0.96 \mathrm{unit} / \mathrm{mg}$ in the presence of a final total $\mathrm{Mg}^{2+}$ concentration of $12 \mu \mathrm{M}$ (concentration of MI $8.7 \mu \mathrm{M}$ ), and an activity of 0.49 unit $/ \mathrm{mg}$ in the presence of a final total $\mathrm{Mg}^{2+}$ concentration of $4 \mu \mathrm{M}$ (concentration of MI $2.9 \mu \mathrm{M}$ ). Since the observed activities thus equal respectively one-half and onequarter of the expected activity, we could estimate that $K_{\mathrm{dE}(\mathrm{MI})}=$ $9 \mu \mathrm{M}$. This value is of the same order of magnitude as for Pinus isocitrate lyase $(3 \mu \mathrm{M})[6]$ and the $C$. acremonium enzyme $(15.6 \mu \mathrm{M})$ [8].

\section{Hysteretic behaviour of maize isocitrate lyase}

Again the metal-free enzyme was incubated at $25^{\circ} \mathrm{C}$ in the presence of increasing concentrations of $\mathrm{MgCl}_{2}$, but its activity was now measured without the addition of $\mathrm{MgCl}_{2}$ to the assay solution (Figure 3A). The $\mathrm{Mg}^{2+}$ concentration during the assay then depends on both the concentration in the re-activating sample and the amount of sample added to the cuvette. We are now able to calculate, for each experimental condition, the fraction of each of the molecular species [E, ME, E(MI), ME(MI)] present in the sample, if we take into account the abovedetermined values for the dissociation constants, i.e. $K_{\mathrm{dME}}=$ $200 \mu \mathrm{M}, K_{\mathrm{dMEM}}=6 \mathrm{mM}$ and $K_{\mathrm{dE}(\mathrm{MI})}=9 \mu \mathrm{M}$, and if we assume that, as for $P$. pinea isocitrate lyase, $K_{\mathrm{dME}(\mathrm{MI})}=60 \mu \mathrm{M}$. The accuracy of the latter assumption is also demonstrated by the fact that the mean value of $K_{\mathrm{dE}(\mathrm{MI})}$ and $K_{\mathrm{dME}(\mathrm{MI})}(34.5 \mu \mathrm{M})$ corresponds closely to the $K_{\mathrm{m}}$ of maize isocitrate lyase, which we determined to be $36 \mu \mathrm{M}$ in $50 \mathrm{mM}$ triethanolamine buffer, $\mathrm{pH} 7.4$ (measurements performed keeping the free $\mathrm{Mg}^{2+}$ concentration constant, i.e. at $0.3 \mathrm{mM}$ or $3 \mathrm{mM}$, and plotting $1 / v$ against
$1 /[\mathrm{MI}]$ with $\mathrm{MI}$ concentrations ranging between 2 and $50 \mu \mathrm{M}$; results not shown). From the knowledge that the activity of $\mathrm{E}$ amounts to $40 \%$ of the activity of $\mathrm{ME}$, we can for each experimental condition calculate the theoretically expected activity by simple arithmetic. It is obvious from the results presented (Figure 3A) that most observed activities substantially exceed the expected values. However, the experimentally determined and calculated activities agree with each other when a $K_{\mathrm{dME}^{*}}$ of $40 \mu \mathrm{M}$ is assumed.

To explain these observations, the following model is proposed. When metal-free isocitrate lyase is incubated (at $25^{\circ} \mathrm{C}$ ) with low concentrations of $\mathrm{MgCl}_{2}$, the high-affinity site for $\mathrm{Mg}^{2+}$ is restored and $K_{\mathrm{dME}}=200 \mu \mathrm{M}$. When more $\mathrm{Mg}^{2+}$ is added, the cation starts binding at the low-affinity binding site $\left(K_{\mathrm{dM} \mathrm{ЕM}}=6 \mathrm{mM}\right)$, thereby inducing a conformational change in the high-affinity site and increasing the affinity of the latter for the metal. The new dissociation constant $\left(K_{\mathrm{dME}^{*}}\right)$ now decreases to $40 \mu \mathrm{M}$. When the $\mathrm{Mg}^{2+}$ concentration is lowered again, the high-affinity binding site is not reconverted instantaneously to its original structure, but remains in the newly adopted conformation for a certain period of time. The dissociation constant will then only gradually go from $K_{\mathrm{dME}^{*}}=40 \mu \mathrm{M}$ to $K_{\mathrm{dME}}=200 \mu \mathrm{M}$. Such behaviour, where the enzyme only slowly responds to a rapid change in ligand concentration, is known as 'hysteresis'. The time of conversion from one form to the other has been shown to vary for different enzymes between seconds and minutes [16,17]. This hypothesis allows our experimental data to fit the theoretically calculated values very well. The possible maize isocitrate lyase conformers and their kinetics may thus be summarized as depicted in Scheme 1.

When the activity of an isocitrate lyase solution containing $240 \mathrm{mM} \mathrm{MgCl}{ }_{2}$ was measured using assay solutions without $\mathrm{MgCl}_{2}$, the final metal concentration depends on the sample volume added to the cuvette. Also here the experimentally observed activities corroborate the theoretical points calculated according to the hysteresis model for isocitrate lyase (Figure 4A).

In order to confirm further the hysteretic behaviour of isocitrate 
lyase, we determined, at various intervals of time, the activity of enzyme molecules that were originally dissolved in buffer containing $240 \mathrm{mM} \mathrm{MgCl}$ (i.e. where both the low- and the highaffinity sites are saturated with metal cation) and suddenly diluted into buffer devoid of metal (Figures $4 \mathrm{~B}$ and 4C). The final $\mathrm{Mg}^{2+}$ concentration in the sample was thereby reduced to $240 \mu \mathrm{M}$. Theoretically, and according to the model depicted in Scheme 1, the activity at the moment of dilution would amount to $92 \%$ of the initial activity (all molecules establishing a $K_{\mathrm{dM} \mathrm{E}^{*}}$ of $40 \mu \mathrm{M}$ ), and would gradually decrease to $73 \%$ of the initial activity when all enzyme molecules have undergone the conformational change (to molecules showing a $K_{\mathrm{dME}}$ of $200 \mu \mathrm{M}$ ). The activity was observed to decrease biphasically, the initial phase being independent of isocitrate lyase concentration. The second and slow phase on the other hand clearly depends on the concentration. Since the decrease in activity is more pronounced at lower isocitrate lyase concentration, the latter can most probably be attributed to a true inactivation caused by dissociation of the tetrameric enzyme into monomers (or dimers). The fast phase on the other hand can be interpreted as representing a fall in activity as a result of the hysteretic response of the enzyme to $\mathrm{Mg}^{2+}$ binding. The time interval needed for all isocitrate lyase molecules to undergo the conformational change was determined to be $60 \mathrm{~min}$.

We can only speculate about the physiological function of the hysteretic behaviour observed for isocitrate lyase. Since it was shown that saturating the non-catalytic high-affinity binding site results in marked protection of the enzyme against proteolytic degradation, we might assume that this is its true function in vivo. It has indeed been postulated that, in several plant species, the action of a specific proteolytic enzyme initiates the onset of degradation of this key glyoxylic acid-cycle enzyme [18-21]. For $P$. pinea it has even been shown that the proteolytic activity is tightly associated with isocitrate lyase molecules [21]. It may be envisaged that, under certain metabolic conditions, the local $\mathrm{Mg}^{2+}$ concentration in situ at the level of the isocitrate lyase molecules may become temporarily too low to allow saturation of the enzyme's high-affinity sites. It is thus tempting to suggest that the conservation of the protected conformation under such conditions may prevent inappropriate degradation.
The results presented in this paper on Zea mays (Angiosperm), together with those on $P$. pinea (Gymnosperm) [6] and $C$. acremonium (filamentous fungus) [8], clearly indicate that the molecular mechanisms observed for isocitrate lyases are highly conserved in plant species that are phylogenetically far apart. This result suggests that the presence of two $\mathrm{Mg}^{2+}$-binding sites on this enzyme may be of physiological significance.

We thank the Flemish Fund for Scientific Research for financial support. S. B. is a Research Associate of the same Foundation. We thank Professor Em. L. Kanarek for helpful discussions.

\section{REFERENCES}

1 Cioni, M., Pinzauti, G. and Vanni, P. (1981) Comp. Biochem. Physiol. 30B, 1-26

2 Giachetti, E., Pinzauti, G., Bonaccorsi, R., Vincenzini, M. T. and Vanni, P. (1987) Phytochemistry 26, 2439-2446

3 Vanni, P., Giachetti, E., Pinzauti, G. and McFadden, B. A. (1990) Comp. Biochem. Physiol. 95B, 431-458

4 Khan, A. S., Van Driessche, E., Kanarek, L. and Beeckmans, S. (1992) Arch. Biochem. Biophys. 297, 9-18

5 Malhotra, O. P., Srivastava, P. K. and Dwivedi, U. N. (1984) Arch. Biochem. Biophys. 235, 612-617

6 Giachetti, E., Pinzauti, G., Bonaccorsi, R. and Vanni, P. (1988) Eur. J. Biochem. 172, 85-91

7 Giachetti, E. and Vanni, P. (1991) Biochem. J. 276, 223-230

8 Perdiguero, E., de Arriaga, D., Busto, F. and Soler, J. (1995) Biochemistry 34, 6059-6068

9 Dixon, G. H. and Kornberg, H. L. (1959) Biochem. J. 72, 3P

10 Morrison, J. F. (1979) Methods Enzymol. 63, 257-294

11 O'Sullivan, W. J. and Smithers, G. W. (1979) Methods Enzymol. 63, 294-336

12 Duggleby, R. G. and Dennis, D. T. (1970) J. Biol. Chem. 245, 3745-3750

13 Laemmli, U. K. (1970) Nature (London), 227, 680-685

14 Strickland, E. H., Wilcheck, M., Horwitz, J. and Billups, C. (1970) J. Biol. Chem. 245 4168-4177

15 Beeckmans, S. and Kanarek, L. (1983) Biochim. Biophys. Acta 743, 370-378

16 Frieden, C. F. (1970) J. Biol. Chem. 245, 5788-5799

17 Frieden, C. F. (1976) Annu. Rev. Biochem. 48, 471-489

18 Theimer, R. R. (1976) FEBS Lett. 62, 297-300

19 Khan, F. R., Saleemuddin, M., Siddiqi, M. and McFadden, B. A. (1979) J. Biol. Chem. 254, 6938-6944

20 McFadden, B. A. and Hock, B. (1985) Phytochemistry 24, 2847-2850

21 Galassi, C., Giachetti, E., Pinzauti, C. and Vanni, P. (1988) Phytochemistry 27, 1303-1307 